\title{
Associations between the AluI polymorphism of growth hormone gene and production and reproduction traits in a Hungarian Holstein-Friesian bull dam population
}

\begin{abstract}
The aim of this paper was to study the polymorphisms of bovine growth hormone gene. The authors genotyped 363 Hungarian Holstein-Friesian bull dams from 6 farms all over the country. Two variants (L and V) of the bovine growth hormone gene digested with AluI enzyme were identified in the experiment. Genotyping was carried out by PCR-RFLP method.

The frequency data of $\mathrm{L}$ and $\mathrm{V}$ allele was 0.93 and 0.07 respectively. Distribution of the three genotypes were $87.05 \%$ (LL), $12.40 \%$ (LV) and $0.55 \%$ (VV). The studied population was in $\mathrm{H}-\mathrm{W}$ equilibrium considering the genotype distribution.

SPSS 11.0 for Windows was used to reveal the possible correlations between GH genotypes and production and reproduction traits and further statistical analyses.

On the basis of statistical analyses it can be found that VV genotype cows had the longest milking period and LL had the shortest dry period. Both differences were significant. Cows with LV genotype had significantly higher test milking data than LL cows. Furthermore, LV genotype seemed to be advantageous for 305 days lactation milk yield. While milk composition traits, as 305 days milk fat and protein percent showed the opposite tendency, since LL genotyped dams produced significantly higher values in these traits.
\end{abstract}

Key Words: DNA preparation, polymorphism, growth hormone gene, Holstein-Friesian breed, lactational traits

\section{Zusammenfassung}

Titel der Arbeit: Zusammenhänge zwischen AluI Polymorphismus des Wachstumshormongens sowie Milch- und Fortpflanzungsleistungen bei Holstein-Friesian Stammkühen

Ziel der Untersuchungen war die Analyse der Polymorphismen vom Wachstumshormon-Gen beim Rind. Es wurden genetische Untersuchungen bei insgesamt 363 Holstein-Friesian Kühen durchgeführt. Die Versuchstiere stammten aus mehreren Betrieben in unterschiedlichen Teilen Ungarns. Zwei mit AluI Restriktion Enzym gespaltene Varianten des Wachstumshormon-Gens (L und V) wurden identifiziert. Die Analysen der Blutproben wurden mit der PCR-RFLP Methode durchgeführt. Die Häufigkeitswerte der Allele L und V waren 0,93 beziehungsweise 0,07. Die prozentualen Anteile der drei Genotypen betrugen 87,05\% (LL), 12,40\% (LV) und 0,55\% (VV). Die untersuchte Population zeigte sich als genetisch ausgeglichen. Zur statistischen Datenverarbeitung wurde SPSS 10 für Windows genutzt. Es konnte festgestellt werden, dass der L/V Locus bei einigen Merkmalen die Leistungsergebnisse signifikant beeinflusste. Die Laktationszeit war bei den Kühen vom Genotyp VV am längsten. Die kürzeste Trockenperiode wiesen die Kühe von Genotyp LL auf. Die Ergebnisse der Probemelkungen waren bei den Kühen von Genotyp LV signifikant besser als bei ihren Zeitgefährten von Genotyp LL. Die höchste 305-Tage-Produktion (Laktationsleistung) konnte bei den Kühen vom Genotyp LV registriert werden. Die prozentualen Anteile von Milchfett und -protein waren dagegen bei den Kühen von Genotyp LL höher. Die Unterschiede zwischen den Genotypen waren statistisch gesichert.

Schlüsselwörter: DNA Isolierung, Polymorphismen, Wachstumshormon-Gen, Holstein-Friesian Kühe, Laktationsleistung

\section{Introduction}

Prediction of the future performance of farm animals is maybe the most neuralgic point in animal breeding. Animals of superior traits and phenotype should be selected to accelerate genetic improvement. Disclosure of the genetic background with the help 
of the modern techniques of molecular genetics could directly establish the genetic merit of the individual. With the development of molecular cloning and DNA hybridization techniques, it has become possible to screen for genetic polymorphism at the nucleic acid level (BUITKAMP and GÖTZ, 2004).

Selection in dairy breeding is basically aimed at milk production traits. Steroid and protein hormones (such as growth hormone and PRL) are of primary importance in development and function of the mammary gland (KAZMER et al., 1983, 1986). Milk production was found as a typical polygenic trait controlled by numerous genetic loci and influenced by environmental factors. Therefore candidate genes with close linkage of the encoding loci are searched to estimate lactational performance (DYBUS et al., 2004).

Growth hormone $(\mathrm{GH})$ belongs to a family of somatolactogenic hormones that have included prolactin, placental lactogen and a number of haematopoetic growth factors (COSMAN et al., 1990).

We focus on one of the most significant members of this hormone family, the bovine growth hormone (bGH), which is a single-chain polypeptide with 22KDa molecular weight. The hormone consists of two disulphide bridges and 190 or 191 amino acids, containing Ala or Phe at the $\mathrm{N}$ terminus, due to alternative processing of $\mathrm{bGH}$ precursors (WOOD et al., 1989) Due to the allele dependent variability, leucine or valine may appear in position 127 (SEAVEY et al., 1971). Bovine GH stimulate postnatal somatic growth. GH, also has diabetogenic, insulin-like and lactogenic effects in vivo. It coordinates physiological processes so that nutrients are partitioned for milk synthesis (BAUMAN and EPPARD, 1985).

Numbers of studies have dealt with the influence of long term administration of bovine GH on lactational performance. Recombinant GH increased the average fat corrected milk yield in a greater extent than GH of pituitary origin (BAUMAN and EPPARD, 1985).

Bovine GH gene is approximately 1800 (1793) base-pairs in length and contains four intervening sequences and five exons coding for a 786 long mRNA (WOYCHIK et al., 1982). GH locus is mapped on cattle chromosome 19 in the region of bands q26-qter (HEDIGER et al., 1990).

Several polymorphisms were found in $\mathrm{GH}$ gene and these pheno/genotypes are inherited in allelic fashion (BECKMANN et al., 1986). In case the bovine GH gene was digested with $M s p I$ restriction endonuclease, two alleles were identified within intron 3. (C and D) (ZHANG et al., 1993a). Digestion of C allele with MspI generated 4 fragments, while the product of the $\mathrm{D}$ allele yielded 3 fragments. The MspI(-) polymorphism results from an insertion of a $\mathrm{T} 837 \mathrm{bp}$ and a C-G transition 838 downstream from the Cap site (LEE et al., 1994a) (see the Figure).

ZHANG et al., (1993b) digested a fragment of bGH gene (containing exon 5) by AluI endonuclease and the found alleles were designated as $\mathrm{L}$ and $\mathrm{V}$. The $\mathrm{L}$ allele is responsible for the form of bGH with an amino acid residue of leucine at position 127, whereas the $\mathrm{V}$ allele is responsible for an alternative form with a valine residue at the same position (see the Figure). The effect of these two alleles was studied thoroughly and contradictory results were born (see Table 12.). The association of these allelic variants with milk production traits among the daughters of Canadian Holstein AI bulls was investigated in the study of SABOUR and LIN (1996) Their results suggested that the $\mathrm{V}$ allele was preferred for increased milk production traits, 
particularly protein. CHUNG et al. (1996) found that the effects of bGH locus were significant for milk protein percentage. Cows with the LL genotype had higher protein percentage than those with LV type. SABOUR et al. (1997) found association between the L/V locus and estimated transmitting abilities (ETA) of milk yield in Holstein Cattle. V allele was more frequent in the top than in the bottom group of bulls. DYBUS (2002) studied the direct lactational data and got similar conclusions. It was proven that cows with LL genotype had higher milk, fat and protein yield compared to LV individuals. Beef characteristics were also studied in bulls of different breed and GH genotype. ZWIERZCHOWSKI et al. (2001) concluded that the L/V locus affected live body weight, and daily weight gain. The VV homozygotes were the heaviest and showed the highest daily gain. Nine carcass traits were also influenced by this polymorphism and again bulls with VV genotype proved to be the best. Contrary to this, SIROTKIN et al. (2000) found that VV genotype Simmental bulls had significantly lower body mass, daily gain and plasma IGF-I level comparing to the other two genotypes.

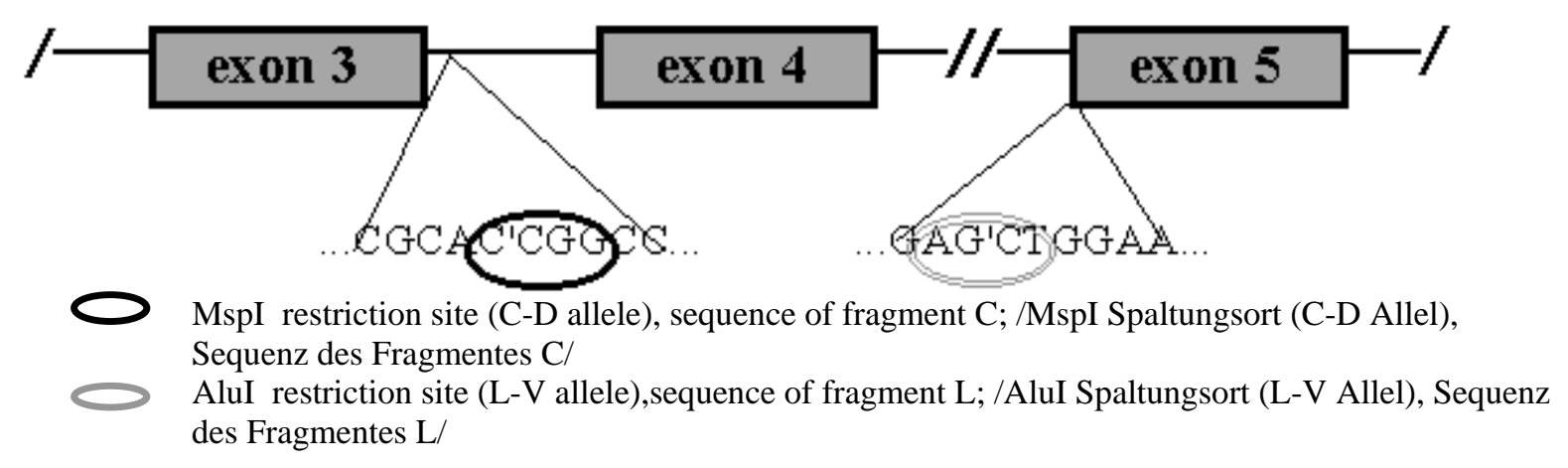

Fig.: The two most frequently studied polymorphisms of the bovine growth hormone gene (Die bekanntesten Polymorphismen des Wachstumshormongens des Rindes)

The association between the controlling hormone (growth hormone releasing hormone, GHRH) gene variants and growth features were also scutinized in beef cattle. GHRH genotypes showed significant correlation with height at sacrum and height at withers (DYBUS et al., 2003).

Beside growth hormone, the influence of milk proteins on milk production has equal importance. The association between polymorphisms in genes coded milk proteins and milk production and fertility was scrutinised by VÁGI and BARANYI, 2000. Hungarian Holstein Friesian cows were involved and the probable effects of the different genotypes of $\alpha_{s 1}-$, $\beta$ - and $\kappa$-kazein and $\beta$-lactoglobulin were studied in the experiment. $\mathrm{K}$-kazein and $\beta$-lactoglobulin genotypes affected milk production and fertility in a greater extent than the other milk protein loci. Heterozygote $\kappa$-kazein cows had significantly higher milk yield in the first lactation comparing to their homozygote herdmates.

Despite of the wide spread study of bovine growth hormone polymorphisms, no published reports are available for Hungarian dairy cattle. The aim of this present study was to explore the frequency of AluI alleles in the Hungarian Holstein-Friesian dam population and to analyse the possible relationship between the investigated bGH locus and milk production traits. 


\section{Animals}

\section{Material and Methods}

A representative sample of the Hungarian Holstein-Friesian bull dam population was used in this study. 363 dams from 6 herds throughout Hungary represent the whole Holstein-Friesian dam herd. Blood samples were collected from all animals by jugular venipuncture and the peripheral blood was saved in tubes containing ethylene diamine tetra-acetic acid. DNA was obtained from blood leucocytes. Blood samples were stored on $-20^{\circ} \mathrm{C}$ until DNA extraction.

\section{DNA Extraction}

Genomic DNA was isolated from $50 \mu$ of whole blood. Samples were washed by 500 $\mu \mathrm{l}$ solution (Tris- $\mathrm{HCl} 10 \mathrm{mM}, \mathrm{pH} 7.5, \mathrm{Na}_{2}$ EDTA $1 \mathrm{mM}$, pH 8) three times in Eppendorf tubes. Vorting and centrifugation for 2 min were followed by each washing procedure. The pellet was suspended in $100 \mu \mathrm{l}$ of lyses solution (Tris 10mM, pH 7.5; KCl $50 \mathrm{mM}$, tween $20 \mathrm{mM} 0.5 \%$; proteinase $\mathrm{K} 0.6 \mu \mathrm{g} / \mu \mathrm{l}$ ). After suspension, samples were incubated at $56^{\circ} \mathrm{C}$ for $60 \mathrm{~min}$. To inactivate the proteinase in the mixture, samples were again incubated at $94^{\circ} \mathrm{C}$ for $10 \mathrm{~min}$. The extracted DNA samples were stored at $-20^{\circ} \mathrm{C}$ and used later as a substrate for PCR reaction.

\section{Primers, PCR conditions and genotyping}

\section{GH F 5’CGGACCGTGTCTATGAGAAGCTGAAG3’}

\section{GH R 5’GTTCTTGAGCAGCGCGTCGTCA3'}

The used primers were designed to amplify a $427 \mathrm{bp}$ fragment using the published DNA sequence of the bGH gene (Genbank Accession Number J00008, Woychik et al. 1982). The 427 bp target DNA contained the site of interest in exon 5, 55 bp of exon 4 and the entire intron 4 . PCR reactions were performed in a total volume of $10 \mu \mathrm{l}$, containing $1 \mathrm{mM} \mathrm{MgCl}_{2}$, $200 \mu \mathrm{M}$ each dNTP, $0.2 \mu \mathrm{M}$ primers, $10 \mathrm{x}$ PCR buffer, 0.5 unit TaqI DNA polymerase (Promega) and 100 ng genomic DNA.

The PCR cycling profile consisted of pre-denaturation at $94^{\circ} \mathrm{C}$ for $1 \mathrm{~min}$, 32 cycles of denaturation at $94^{\circ} \mathrm{C}$ (for $30 \mathrm{sec}$ ), annealing at $61^{\circ} \mathrm{C}$ (for $1 \mathrm{~min}$ ), and extension at $72^{\circ} \mathrm{C}$ (for $1 \mathrm{~min}$ ), followed by a final extension at $72^{\circ} \mathrm{C}$ for $10 \mathrm{~min}$.

PCR products were digested in a total volume of $13 \mu \mathrm{l}$, containing the whole amount of PCR products, 5 units of AluI enzyme and $10 \mathrm{xB}$ buffer (Promega) at $37^{\circ} \mathrm{C}$ fortnight. Digested fragments were then resolved in 4\% high resolution agarose gels (Cambrex) stained with ethidium bromide and visualised under UV light. Gels were scored for expected fragments of 264, 96, 51 and 16 bp for the Leu ${ }^{127}$ variant and 264, 147 and 16 bp for the $\mathrm{Val}^{127}$ variant.

\section{Data sets and statistical analysis}

Lactation and some reproduction data were used to analyse the potential differences in performance of cows caused by the examined polymorphism. Lactation data contained days in milking, persistency, mean milk kg of test milkings, maximum milk kg of test milkings, lactation milk yield, lactation milk fat (kg and \%) and lactation milk protein (kg and \%) recorded between 1989 and 1998. Each lactation record comprised 305day yields for cows lactating for 305 days or more and total lactation yields for cows with shorter lactation, not less than 60 days. Reproduction data included age at first calving, calving interval, number of calvings and dry period. This data package included 6 herds (with animal number of 66-276), 10 years and 4 seasons of calving 
(spring: March-May, summer: June-August, autumn: September-November and winter: December-February). Finally the database consisted of altogether 721 reproduction and lactation records of 363 genotyped bull dams.

Table 1

Descriptive statistics of the studied lactation and reproduction data (Untersuchte Laktations- und Reproduktionsmerkmale zur statistischen Auswertung)

\begin{tabular}{lrrrrr}
\hline \multicolumn{1}{c}{ traits } & \multicolumn{3}{c}{ Descriptive Statistics } \\
number of calvings & $\mathrm{N}$ & Minimum & Maximum & Mean & Std. Deviation \\
\hline age at first calving & 721 & 1 & 4 & 1.74 & 0.89 \\
days between calvings & 363 & 674 & 1100 & 791.42 & 55.92 \\
days in milking & 357 & 311 & 697 & 431.70 & 75.28 \\
dry period & 505 & 240 & 669 & 365.11 & 72.33 \\
max. test milk kg & 496 & 15 & 196 & 60.72 & 21.89 \\
mean test milk kg & 504 & 25.2 & 65.6 & 41.782 & 6.707 \\
persistency & 504 & 16.8 & 48.0 & 33.380 & 4.656 \\
305d milk yield & 510 & 51.8 & 94.6 & 80.453 & 6.534 \\
305d milk fat\% & 720 & 4140 & 15678 & 10044.41 & 1492.16 \\
305d milk fat yield & 717 & 2.40 & 5.89 & 3.4137 & 0.4184 \\
305d milk protein\% & 717 & 171 & 698 & 340.38 & 52.34 \\
305d milk protein yield & 708 & 2.20 & 5.79 & 3.1850 & 0.2265 \\
\hline
\end{tabular}

The presented data in Table 1 show the minimum, maximum and average values of lactation and reproduction traits involved in the experiment. The results represent the gross mean values of the population through years and not separated by farms or numbers of lactation.

\section{Statistical analysis}

The method of univariate and multivariate analysis of variance and estimated marginal means were used to estimate the potential correlations and the effect of the examined locus on lactation data. The SPSS (SPSS 11.0 for Windows) software was used for this analysis. The formula of general linear model (GLM) included the following effects:

$y_{i j k l m}=\mu+G_{i}+$ calving $_{j}+G_{i^{*}}$ calving $_{j}+$ year $_{k}+$ season $_{l}+$ farm $_{m}+e_{i j k l m}$

where $y$ is the phenotypic record of the studied traits, $\mu$ is the general mean, $G H$ is the growth hormone genotype (LL, LV, VV), calving refers to the influence of the number of calvings (first, second, etc), year represents the effect of the year of birth, season indicates the impact of calving season ( $\mathrm{n}=1-4)$ (weather, quality of feed), farm means the farm effect $(\mathrm{n}=1-6)$ and $e$ is the residual error.

Dominance effects were estimated as the deviation of mean values of the studied traits in heterozygotes from the mean of homozygotes, using the least square means. Additive effect was calculated as the half of the difference between the two homozygotes. The significancy of these factors was detected by the method of least square difference.

\footnotetext{
Results

Gene frequency

Three patterns (genotypes) were produced as the result of AluI restriction.
} 
Four (LL), three (VV) and five (LV) band patterns could be distinguished on the gel, which are the products of two alleles ( $\mathrm{L}$ and $\mathrm{V})$.

The expected allele frequencies were calculated according to the Hardy-Weinberg equilibrium:

$$
\mathrm{P}^{\mathrm{L}}=\frac{2 \mathrm{GH} \mathrm{LL}+\mathrm{GH} \mathrm{LV}}{2 \mathrm{~N}} \text { and } \mathrm{q}^{\mathrm{V}}=\frac{2 \mathrm{GH} \mathrm{VV}+\mathrm{GH} \mathrm{LV}}{2 \mathrm{~N}}
$$

where:

$p^{L}$ and $q^{V}$ are the expected frequencies of $L$ and $V$ alleles, GH LL, GH LV and GH VV are the number of animals with different genotypes $N$ is the number of genotyped animals

$\mathrm{GH} L \mathrm{~L}=\mathrm{nx} \mathrm{p}^{2}$

$\mathrm{GH} \mathrm{VV}=\mathrm{n} \times \mathrm{q}^{2}$

$\mathrm{GH} \mathrm{LV}=2 \mathrm{n} \times \mathrm{p} \times \mathrm{q}$

where: GH LL, GH LV and GH VV are the expected frequencies of the three genotypes

On the basis of the Hardy-Weinberg formulas, the expected frequencies of $\mathrm{L}$ and $\mathrm{V}$ alleles were 0.93 and 0.07 respectively. The expected frequencies of the three genotypes were $86.96 \%$ (LL) $12.59 \%(\mathrm{LV})$ and $0.45 \%(\mathrm{VV})$ respectively. The observed number of genotypes (87.05 \% (LL) $12.40 \%$ (LV) and $0.55 \%$ (VV)) were quite close to the expected values. The calculated $\chi^{2}$ value was 0.111 , indicating Hardy-Weinberg equilibrium in the population (see Table 2).

Table 2

Distribution of GH genotypes in the studied population (Verteilung der GH Genotypen in der untersuchten Population)

\begin{tabular}{cccccc}
\hline Breed & $\mathrm{N}$ & LL & LV & VV & $\chi^{2}$ \\
\hline Hungarian Holstein & 363 & $\mathbf{3 1 6}(315.65)$ & $\mathbf{4 5}(45.70)$ & $\mathbf{2}(1.65)$ & 0.111 \\
Friesian dams & $100 \%$ & $\mathbf{8 7 . 0 5 \% ( 8 6 . 9 6 \% )}$ & $\mathbf{1 2 . 4 0 \% ( 1 2 , 5 9 \% )}$ & $\mathbf{0 . 5 5 \% ( 0 . 4 5 \% )}$ & \\
\hline
\end{tabular}

(The expected values are in brackets. $)(\mathrm{df}=2, \mathrm{p}=0.05)$

There was similar distribution values of genotypes in the different farms (Table 3) than in case of the final genotype distribution for the whole studied population.

Low incidence of VV genotype (2 animals) will cause some statistical uncertainty, but in these cases they are omitted from analysis. These animals are not relatives, not herdmates, they have different fathers and mothers as well, and even they are kept on different farms (see Table 3).

Table 3

Frequencies of genotypes by farms (Verteilung der GH Genotypen pro Betrieb)

\begin{tabular}{lcccc}
\hline & $\mathbf{N}$ & LL (\%) & LV (\%) & VV (\%) \\
\hline Farm 1 & $63(17.4 \%)$ & 88.9 & 11.1 & - \\
Farm 2 & $136(37.5 \%)$ & 92.6 & 7.4 & - \\
Farm 3 & $76(20.9 \%)$ & 77.6 & 21.1 & 1.3 \\
Farm 4 & $33(9.1 \%)$ & 84.8 & 12.1 & 3.0 \\
Farm 5 & $25(6.9 \%)$ & 80.0 & 20.0 & - \\
Farm 6 & $30(8.3 \%)$ & 90.0 & 10.0 & - \\
total & $363(100 \%)$ & 87.1 & 12.4 & 0.6 \\
\hline
\end{tabular}

Table 4 includes mean and standard deviation of studied production and reproduction data seperated by the different GH genotypes. Table 5 shows the lactational data in case of different number of calvings. In case of the statistical analysis, only the first 
four lactations were used since just a few animals finished the subsequent lactations and therefore their results could not be evaluated in reliable way. The analysis of the first four lactations can give an entirely precise picture on milk production either regarding physiological or farm management aspects.

Table 4

Values of the important production and reproduction traits in different GH genotypes (Wert der wichtigen Produktions- und Reproduktionsmerkmale der unterschiedlichen GH Genotypen)

\begin{tabular}{|c|c|c|c|c|c|c|}
\hline \multirow{3}{*}{ traits } & \multicolumn{6}{|c|}{ GH LV locus } \\
\hline & \multicolumn{2}{|c|}{$\mathbf{L L}$} & \multicolumn{2}{|c|}{$\mathbf{L V}$} & \multicolumn{2}{|c|}{ VV } \\
\hline & Mean & $\mathrm{SD}$ & Mean & $\mathrm{SD}$ & Mean & SD \\
\hline age at first calving (days) & 790.37 & 54.05 & 800.4 & 68.3 & 756 & 7.07 \\
\hline Calving interval & 431.69 & 75.77 & 427.3 & 69.08 & 528 & 110.31 \\
\hline days in milking & 362.97 & 70.23 & 373.98 & 81.87 & 454.5 & 87.23 \\
\hline dry period (days) & 59.67 & 22.11 & 68 & 19.48 & 56.25 & 15.5 \\
\hline max. test milk kg & 41.5 & 6.68 & 43.83 & 6.7 & 39.42 & 4.87 \\
\hline mean test milk kg & 33.09 & 4.59 & 35.32 & 4.75 & 33.28 & 4.3 \\
\hline persistency & 80.27 & 6.5 & 81.36 & 6.56 & 84.83 & 8.86 \\
\hline 305d milk yield (kg) & 10003.01 & 1476.48 & 10334.66 & 1591.49 & 10158 & 1308.52 \\
\hline 305d milk fat $\%$ & 3.42 & 0.43 & 3.37 & 0.33 & 3.47 & 0.6 \\
\hline 305d milk fat yield (kg) & 339.46 & 52.19 & 346.62 & 54.33 & 346.75 & 20.52 \\
\hline 305d milk protein\% & 3.19 & 0.23 & 3.14 & 0.2 & 3.18 & 0.29 \\
\hline 305d milk protein yield (kg) & 318.1 & 44.78 & 322.72 & 45.86 & 320.75 & 20.55 \\
\hline
\end{tabular}

Table 5

Means and standard deviations of lactation data per lactations (Mittelwert und Standardabweichung der Laktationsdaten pro Laktation)

\begin{tabular}{|c|c|c|c|c|c|c|c|c|}
\hline \multirow{3}{*}{ traits } & \multicolumn{8}{|c|}{ number of calvings } \\
\hline & \multicolumn{2}{|c|}{1} & \multicolumn{2}{|l|}{2} & \multicolumn{2}{|l|}{3} & \multicolumn{2}{|l|}{4} \\
\hline & Mean & SD & Mean & $\mathrm{SD}$ & Mean & SD & Mean & SD \\
\hline age at first calving (days) & 791.42 & 55.92 & - & - & - & - & - & - \\
\hline days between calvings & - & - & 438.91 & 77.03 & 416.23 & 69.05 & 430.84 & 76.51 \\
\hline days in milking & 374.82 & 71.46 & 356.46 & 76.21 & 354.67 & 68.73 & 346.52 & 49.71 \\
\hline dry period (days) & 62.14 & 17.28 & 56.42 & 22.52 & 60.78 & 27.43 & 75.45 & 37.32 \\
\hline max. test milk kg & 37.856 & 4.403 & 44.948 & 5.922 & 47.699 & 6.13 & 46.791 & 7.548 \\
\hline mean test milk kg & 31.421 & 3.327 & 34.997 & 4.798 & 36.346 & 4.567 & 35.587 & 6.758 \\
\hline persistency & 83.318 & 5.457 & 78.102 & 6.558 & 76.514 & 5.079 & 76.026 & 6.681 \\
\hline 305d milk yield (kg) & 9419.18 & 1154.46 & 10446.57 & 1512.89 & 11027.8 & 1406.01 & 11111.42 & 1696.27 \\
\hline 305d milk fat $\%$ & 3.4348 & 0.4088 & 3.4043 & 0.4537 & 3.3855 & 0.3716 & 3.3413 & 0.4151 \\
\hline 305d milk fat yield (kg) & 320.99 & 37.01 & 353.73 & 61.72 & 371.01 & 47.33 & 368.71 & 57.55 \\
\hline 305d milk protein\% & 3.207 & 0.1863 & 3.1736 & 0.2862 & 3.1461 & 0.2039 & 3.1392 & 0.2308 \\
\hline 305d milk protein yield (kg) & 301.27 & 32.22 & 330.18 & 51.52 & 346.33 & 38.91 & 348.43 & 49.86 \\
\hline
\end{tabular}

\section{The effects of the AluI polymorphism of GH gene on milk production traits}

The effects of factors involved in the used mathematical model were calculated and the levels of significance were presented in Table 6. The most frequently used multivariate analyses (U statistic) was used to estimate the effects of factors. The effect of GH locus was significant on milk production traits. However the intercept of GH locus and calvings did not influence the studied traits significantly. On the other hand, subsequent lactations (calvings), the year of birth, and farm showed highly signifinat effects if total sum of the traits were regarded.

The influence of the studied factors are classified by reproduction and milk production traits and shown in Table 7. On the basis of the presented significance levels, it can be 
seen that GH genotype affected 305 days milk protein percent significantly. Data of test milkings are influenced by only a slight significant level, but reproduction and other milk production performances were not affected significantly by GH locus.

Table 6

Significance levels of effects used in the design on the basis of multivariate analysis of variance (U statistics) (Ergebnisse der multiplen Varianzanalyse)

\begin{tabular}{ll}
\hline Effect & Significance \\
\hline GH genotype & $0.010^{*}$ \\
calvings & $0.0001^{* * *}$ \\
GH genotype x calving & 0.922 \\
birth year & $0.0001^{* * *}$ \\
calving season & $0.013^{*}$ \\
farm & $0.0001^{* * *}$ \\
\hline
\end{tabular}

Design: $\mu+G_{i}+$ calving $_{j}+G_{i^{*}}$ calving $_{j}+$ year $_{k}+$ season $_{l}+$ farm $_{m}+e_{i j k l m}$

$(*: \mathrm{p}<0.05 ; * * \mathrm{p}<0.01, * * * \mathrm{p}<0.005)$

\section{Table 7}

Significance levels for the studied traits according to the analysed effects on the basis of test of between subject effects of multivariate analysis (Signifikanz der analysierten Effekte bei den untersuchten Merkmalen auf der Grundlage von Test und multipler Analyse)

\begin{tabular}{|c|c|c|c|c|c|c|}
\hline \multirow[b]{2}{*}{ traits } & \multirow[b]{2}{*}{ GH genotype } & \multirow[b]{2}{*}{ calving } & \multicolumn{2}{|c|}{ source of variation } & \multirow[b]{2}{*}{ season } & \multirow[b]{2}{*}{ farm } \\
\hline & & & $\begin{array}{l}\text { Gh genotype } \\
\text { x calving }\end{array}$ & year & & \\
\hline age at first calving & 0.394 & - & - & 0.159 & 0.560 & $0.0001^{* * *}$ \\
\hline calving interval & 0.141 & - & - & $0.032 *$ & $0.011^{*}$ & 0.908 \\
\hline days in milking & 0.128 & 0.070 & 0.863 & $0.0001 * * *$ & 0.345 & 0.498 \\
\hline dry period & 0.307 & 0.986 & 0.530 & $0.009 * *$ & 0.082 & 0.084 \\
\hline max. test milk kg & 0.096 & $0.0001^{* * *}$ & 0.966 & 0.076 & $0.016 *$ & 0.082 \\
\hline mean test milk kg & 0.097 & $0.0001 * * *$ & 0.698 & 0.376 & 0.078 & $0.036 *$ \\
\hline persistency & 0.643 & $0.0001^{* * *}$ & 0.671 & $0.010 *$ & 0.082 & $0.0001 * * *$ \\
\hline 305d milk yield & 0.572 & $0.002 * *$ & 0.839 & 0.211 & 0.126 & 0.329 \\
\hline 305d milk fat $\%$ & 0.743 & 0.840 & 0.802 & 0.049* & 0.153 & $0.0001^{* * *}$ \\
\hline 305d milk fat yield & 0.866 & $0.002 * *$ & 0.997 & 0.459 & 0.078 & $0.001 * * *$ \\
\hline 305d milk protein \% & $0.009 * *$ & 0.266 & 0.868 & $0.019 *$ & 0.019* & $0.0001^{* * *}$ \\
\hline 305d milk protein yield & 0.821 & $0.008 * *$ & 0.550 & 0.187 & 0.297 & 0.107 \\
\hline
\end{tabular}
$\left({ }^{*}: \mathrm{p}<0.05 ;{ }^{* *} \mathrm{p}<0.01,{ }^{* * *} \mathrm{p}<0.005\right)$

Number of calvings significantly influenced maximum test milk kg, mean test milk kg, persistency, 305 days milk yield, 305 days milk fat yield and 305 days milk protein yiled. It is clear that the level of milk production strongly depends on the number of finished lactations. We studied four, statistically valuable lactation with increasing milk production level (see Table 5).

The interaction between GH genotype and calving had significant effect on neither traits. This mean that the assumed interaction between GH locus and number of lactations does not work and do not influence the phenotypic performance of animals.

Birth year of cows influenced calving interval, days in milking, dry period, persistency, 305 days milk fat and 305 days milk protein percent. This fact refers to the supposed breeding improvement in Hungarian bull dam breeding through years. The factor of calving season, through differences in feeding and climatic features, significantly affected calving interval, maximum test milk $\mathrm{kg}$ and 305 days milk protein percent. However, the lenght of dry period, mean test milk kg, persistency and 305 days milk fat yield was also slightly influenced by this factor.

Beside the influence of the subsequent lactations, farm effect was the kind of external factor which could cause the biggest differences between performances. The different 
management and feeding protocoll and the various microclimates of farms could be responsible for such significant differences. Farm had highly significant effects on age at first calving, persistency, 305 days milk fat yield and percent and milk protein percent. Its effect was not so strong but significant in case of mean test milk kg and slightly significant on dry period, maximum test milk kg and lactation protein yield.

Least square means for reproduction and milk production traits are presented in Table 8-10. In case of reproductive performance, no significant relationship could be detected between age at first calving and calving interval and the three GH-AluI genotypes. Major differences of LSD could be measured in both traits in case of cows with VV genotype comparing to others, but they were not proved to be significant because of the few records and the high levels of standard error.

Table 8

Least square means and standard error for reproduction traits by GH genotype (Schätzwerte nach der Methode der kleinsten Quadrate und Standardfehler der Reproduktionsmerkmale bei GH Genotypen)

\begin{tabular}{|c|c|c|}
\hline \multirow[b]{2}{*}{ GH genotype } & \multicolumn{2}{|c|}{$\mathrm{LSD} \pm \mathrm{SE}$} \\
\hline & age at first calving & calving interval \\
\hline$\overline{\mathbf{L L}}$ & $788.86 \pm 10.83$ & $435.88 \pm 9.84$ \\
\hline $\mathbf{L V}$ & $796.44 \pm 13.26$ & $425.89 \pm 14.72$ \\
\hline VV & $749.09 \pm 40.19$ & $530.07 \pm 53.67$ \\
\hline
\end{tabular}

Next Table represents the differences between GH genotypes in milk production characterized by some considerable traits. The length of milking period (in days) differed significantly among genotypes. Cows with LL and LV genotypes had significantly shorter milking period than in case of VV genotype, but there was no significant differences between the data of LL and LV cows. If the length of dry period is considered, significant difference could be detected between LL and LV cows, with longer dry period in case of LV animals. The shortest dry periods of VV cows were not significant because the high standard error. The same relationship can be observed in case of the maximum and mean of test milkings. Dams with LV genotype had significantly higher values in both traits comparing to LL animals. VV cows again differed significantly to neither genotypes. Results of persistency did not show any significance among the three genotypes.

Table 9

Least square means and standard error for milk production traits by GH genotype (Schätzwerte nach der Methode der kleinsten Quadrate und Standardfehler der Milchproduktionsmerkmale bei GH Genotypen)

\begin{tabular}{lccccc}
\hline GH genotype & days in milking & dry period & $\begin{array}{c}\text { LSD } \pm S E \\
\text { max. test milk kg }\end{array}$ & mean test milk kg & persistency \\
\hline LL & $358.14 \pm 5.54 \mathrm{a}$ & $62.44 \pm 1.65 \mathrm{a}$ & $44.33 \pm 0.41 \mathrm{a}$ & $34.33 \pm 0.318 \mathrm{a}$ & $77.82 \pm 0.45$ \\
LV & $354.39 \pm 14.83 \mathrm{a}$ & $68.55 \pm 4.42 \mathrm{~b}$ & $46.42 \pm 1.09 \mathrm{~b}$ & $36.15 \pm 0.85 \mathrm{~b}$ & $77.97 \pm 1.19$ \\
VV & $448.02 \pm 35.78 \mathrm{~b}$ & $55.79 \pm 10.68 \mathrm{ab}$ & $38.78 \pm 2.62 \mathrm{ab}$ & $32.29 \pm 2.05 \mathrm{ab}$ & $83.75 \pm 2.87$ \\
\hline \multicolumn{7}{l}{ (letter a, b: different letters indicate significant difference between genotypes, ab shows a non-significant relationship) }
\end{tabular}

Results of the 305 days lactations were also compared between the GH AluI variants (Table 10). LV genotype was proved to be favourable in 305 days lactation yield. This production gain was significant comparing to LL cows. VV genotype showed significant relationship with neither genotypes in neither cases due to too few records and considerably high standard error. There was no detectable significant difference in 305 days milk fat and protein yield. However, the performance of LL genotyped cows was significantly higher, compared to the similar values of LV cows, in case of 305 
days milk fat and protein percent. LV genotype is rather favourable in milk composition traits.

Table 10

Least square means and standard error for 305 days lactation yields by GH genotype (Schätzwerte nach der Methode der kleinsten Quadrate und Standardfehler der 305 Tage Laktationsergebnisse bei GH Genotypen)

\begin{tabular}{|c|c|c|c|c|c|}
\hline \multirow[b]{2}{*}{ GH genotype } & \multicolumn{5}{|c|}{$\overline{L S D} \pm S E$} \\
\hline & 305d milk yield & 305d fat\% & 305d fat yield & 305d protein \% & 305d protein yield \\
\hline$\overline{\mathbf{L L}}$ & $10337.5 \pm 105.51 \mathrm{a}$ & $3.43 \pm 0.03 a$ & $352.04 \pm 3.68$ & $3.175 \pm 0.014 a$ & $326.56 \pm 3.04$ \\
\hline LV & $10634.6 \pm 282.40 \mathrm{~b}$ & $3.39 \pm 0.08 \mathrm{~b}$ & $357.55 \pm 9.84$ & $3.05 \pm 0.04 \mathrm{~b}$ & $322.07 \pm 8.14$ \\
\hline VV & $9905.0 \pm 681.49 \mathrm{ab}$ & $3.51 \pm 0.20 \mathrm{ab}$ & $340.73 \pm 23.76$ & $3.18 \pm 0.09 \mathrm{ab}$ & $311.85 \pm 19.64$ \\
\hline
\end{tabular}

(letter a, b: different letters indicate significant difference among genotypes while ab shows a non-significant relationship)

Additive and dominance effects for 305 days lactation yields are presented in Table 11. Additive effects estimated on the basis of least square means were found significant in neither traits nor lactations. However, significant dominance was detected by the method of least square difference in case of 305 days milk yield, milk fat and milk protein percent. Though it should be pointed out that in case of 305 days milk fat and prtein percent a negative dominance was found due to the lower heterozygote means (LSM).

Table 11

Least square means of milk production traits by GH genotypes and the additive and dominance effects (Schätzwerte nach der Methode der kleinsten Quadrate der Milchproduktionsmerkmale der GH Genotypen, additive und dominante Effekte)

\begin{tabular}{lrrrrc}
\hline \multicolumn{1}{c}{ traits } & \multicolumn{1}{c}{ GH genotype } & \multicolumn{1}{c}{ VV } & additive effect & dominance \\
\hline 305d milk yield & $10337.5 \pm 105.5 \mathrm{a}$ & $10634.6 \pm 282.4 \mathrm{~b}$ & $9905.0 \pm 681.5 \mathrm{ab}$ & 216.25 & $513.35^{*}$ \\
305d fat\% & $3.43 \pm 0.03 \mathrm{a}$ & $3.39 \pm 0.08 \mathrm{~b}$ & $3.51 \pm 0.20 \mathrm{ab}$ & 0.04 & $-0.08^{*}$ \\
305d fat kg & $352.0 \pm 3.7$ & $357.6 \pm 9.8$ & $340.7 \pm 23.8$ & 5.65 & 11.25 \\
305d protein\% & $3.18 \pm 0.01 \mathrm{a}$ & $3.05 \pm 0.04 \mathrm{~b}$ & $3.18 \pm 0.09 \mathrm{ab}$ & 0 & $-0.13^{*}$ \\
305d protein kg & $326.6 \pm 3.0$ & $322.1 \pm 8.1$ & $311.9 \pm 19.7$ & 7.35 & 2.85 \\
\hline
\end{tabular}

(letter a, b: different letters indicate significant difference among genotypes, while $\mathrm{n}$ shows a non-significant relationship) (* shows the reliability of the estimated factors $(\mathrm{P}<0.05))$

\section{Discussion}

The found allele and genotype frequencies did not differ from the data of other studies. ZHANG et al. (1993) found similar frequency values (L: 0.91; V: 0.09), in a HolsteinFriesian AI bull population. Results of SABOUR and LIN (1996) in Canadian Holstein-Friesian bulls (V:0.09) also support the GH allele frequency data found in our study.

On the basis of the statistical analyses, it can be concluded that highly strong relationship between GH genotype and milk production or reproduction traits could not be detected. Milk production and reproduction traits were mainly and highly significantly influenced by the farm environment, management and feeding. The effect of birth year was also decisive, since the production level obviously increased through years according to the breeding requirements. The significant influence of calving season could also be identified due to the different climatic factors and rarely the different feeding management. Finally, undoubtedly milk production was strongly affected by the number of closed lactations. However, the used mathematical models were able to distinguish and separate the part of differences among the studied GH genotypes due to external factors and genetical background. Therefore significant 
influences of GH genotype on milk production and reproduction could be found in particular traits. VV genotype cows had the longest period spent with milking and LL had the shortest dry period. Both differences were proved to be significant. Cows with LV GH AluI genotype had significantly higher test milking data than LL cows. Furthermore, LV genotype seemed to be advantageous for 305 days lactation milk yield. While milk composition traits, as 305 days milk fat and protein percent showed the opposite tendency, since LL genotyped dams produced significantly higher values in these traits.

Table 12

The effect and frequency of the L/V polymorphism of GH gene in different breeds based on literature data (Literaturdaten über Einfluss und Frequenz von L/V Polymorphismen des GH Gens in unterschiedlichen Rinderrassen)

\begin{tabular}{|c|c|c|c|c|c|}
\hline breed & $\begin{array}{c}\text { No. of } \\
\text { animals }\end{array}$ & $\begin{array}{c}\text { freq. of } \\
\text { L } \\
\text { variant }\end{array}$ & trait & $\begin{array}{l}\text { preferred } \\
\text { genotype }\end{array}$ & reference \\
\hline $\begin{array}{l}\text { German Black and } \\
\text { White bulls }\end{array}$ & 23 & 0.8 & GH concentration & LL & Schlee et al. (1994) \\
\hline $\begin{array}{l}\text { Bavarian } \\
\text { bulls }\end{array}$ & 20 & 0.9 & GH concentration & LL & Schlee et al. (1994) \\
\hline $\begin{array}{l}\text { Bavarian Simmental } \\
\text { bulls }\end{array}$ & 41 & 0.71 & GH concentration & LL & Schlee et al. (1994) \\
\hline $\begin{array}{l}\text { Canadian } \\
\text { bulls }\end{array}$ & 100 & 0.91 & $\begin{array}{l}\text { ETA for milk } \\
\text { production }\end{array}$ & V allele & Sabour \& Lin (1996) \\
\hline dairy cattle & & 0.74 & milk protein \% & LL & Chung et al. (1996) \\
\hline Ayrshire bulls & 100 & 0.71 & $\begin{array}{l}\text { ETA for milk fat and } \\
\text { protein }\end{array}$ & V allele & Sabour et al. (1997) \\
\hline Holstein bulls & 51 & 0.91 & $\begin{array}{l}\text { ETA for milk fat and } \\
\text { protein }\end{array}$ & V allele & Sabour et al. (1997) \\
\hline Jersey bulls & 21 & 0.76 & $\begin{array}{l}\text { ETA for milk fat and } \\
\text { protein }\end{array}$ & V allele & Sabour et al. (1997) \\
\hline Holstein-Friesian & 184 & - & GH concentration & VV & Grochowska et al. (1997) \\
\hline Holstein-Friesian & 184 & - & GH release & LV & Grochowska et al. (1997) \\
\hline Danish Holstein & 568 & 0.93 & GH release & $\mathrm{L}$ allele & Lovendahl et al. (1997) \\
\hline Red Danish & 145 & 0.83 & GH release & L allele & Lovendahl et al. (1997) \\
\hline Danish Jersey & 74 & 0.53 & GH release & L allele & Lovendahl et al. (1997) \\
\hline Slovak Pied & 95 & 0.55 & $\begin{array}{l}\text { body weight, daily } \\
\text { gain }\end{array}$ & LL & Chrenek et al. (1998) \\
\hline Slovak Pinzgauer & 80 & 0.55 & - & - & Chrenek et al. (1998) \\
\hline Slovak Holstein & 75 & 0.72 & - & - & Chrenek et al. (1998) \\
\hline Holstein-Friesian & 477 & 0.82 & milk, fat, protein yield & $\mathrm{L}$ allele & Shariflou et al. (1998) \\
\hline Polish Friesian & 265 & 0.61 & $\begin{array}{l}\text { body weight at } 7 \& 8 \\
\text { month of age }\end{array}$ & LV & $\begin{array}{l}\text { Zwierzchowski et al. } \\
\text { (1998) }\end{array}$ \\
\hline Polish Friesian bull & 142 & 059 & meat deposition & L allele & Oprzadek et al. (1999) \\
\hline Brown Swiss & 107 & 0.5 & milk fat \& protein \% & $\mathrm{LL}$ & Chrenek et al. (1999) \\
\hline Australian Holstein & 384 & 0.82 & milk, fat,protein yield & L allele & Shariflou et al. (2000) \\
\hline beef bulls & 68 & - & $\begin{array}{l}\text { body weight, daily } \\
\text { gain }\end{array}$ & VV & $\begin{array}{l}\text { Zwierzchowski et al. } \\
\text { (2001) }\end{array}$ \\
\hline Polish Limousine & 102 & 0.64 & - & - & Dybus et al. (2002) \\
\hline Holstein-Friesian & 1086 & 082 & milk, fat,protein yield & LL & Dybus (2002) \\
\hline
\end{tabular}

The findings of SHARIFLOU et al. (2000) seem to be also opposite with the present study. They found in Australian Holstein Friesian cows that animals with $\mathrm{L} / \mathrm{L}$ and $\mathrm{L} / \mathrm{V}$ genotypes had similar performances, each being significantly greater than cows with V/V genotype. So, it was concluded that L allele was associated with higher milk production. 
Table 12 summarizes the results and important findings of the former studies about AluI polimorphism of bovine $\mathrm{GH}$ gene. It helps to compare the sometimes contradictory consequences on the possible effect of the studied polymorphism.

As a conlusion it can be stated that the studied Hungarian Holstein Friesian dam population was not uniform enough to examine the effect of the different GH AluI polymorphism on production and reproduction traits. The extremely low incidence of the homozygous VV genotype also hindered the statistical results. Despite of all, the benefical effect of LV genotype (containing $\mathrm{V}$ allele) in milk yield and LL genotype (missing $\mathrm{V}$ allele) in milk composition could be detected in a relieble way. Examination and GH genotyping of a large cow population kept under uniform circumstances shall further contribute to the use of $\mathrm{GH}$ gene as a marker for the improvement of milk production.

Similarly to our results SABOUR and LIN (1996) studied Canadian Holstein AI bulls and found that the $\mathrm{V}$ allele was preferred for increased milk production traits. Similarly, SABOUR et al. (1997) found association between the L/V locus and estimated transmitting abilities (ETA) of milk yield in Holstein breed. The V allele was more frequent in the top group of bulls. These findings are supported also by EPPARD et al. (1992) who reported that the V variant of GH resulted in higher milk production when administered intramuscularly in Holstein-Friesian cows. If milk composition is concerned, the paper of DYBUS (2002) must be referred, who studied the direct lactational data and proved that cows with LL genotype had higher milk fat and protein yield compared to LV individuals.

Contrary to the above mentioned studies and to us, LUCY et al. (1993) reported that L allele is closely related with higher milk production traits for US Holsteins, whereas in US Jerseys the V allele is associated with higher milk yield. In US Ayrshires there is no correlation proved with milk production.

\section{References}

BAUMAN, D.E.; EPPARD, P.J.:

Responses of high producing dairy cows to long-term treatment with pituitary somatotropin and recombinant somatotropin. J. Dairy Sci. 68 (1985), 1352-1362

BECKMANN, J.S.; KASHI, Y.; HALLERMAN, E.M.; NAVE A.; SOLLER M.:

Restriction fragment length polymorphism among Israeli Holstein-Friesian dairy bulls. Anim. Genet., 17 (1986), 25-38

BUITKAMP, J.; GÖTZ, K.-U.:

Use of milk samples from an evaluation program for the genotyping of cows. Arch. Tierz., Dummerstorf 47 (2004) 1, 15-26

CHRENEK, P.; HUBA, J.; ORAVCOVÁ, M.; HETÉNYI, L.; PESKOVIÉOVÁ, D.; BULLA, J.:

Genotypes of bGH and bPRL genes in relationships to milk production. Rewiev of the $50^{\text {th }}$ EAAP Meting (1999), Ga4.15

CHRENEK, P.; KMET, J.; SAKOWSKI, T.; VASICEK, D.; HUBA, J.; CHRENEK J.:

Relationships of GH genotypes with meat production trait of Slovak Pied bulls. Czech J. Anim. Sci., 43 (1998), 541-544

CHUNG, E.R.; RHIM, T.J.; HAN, S.K.:

Associations between PCR-RFLP markers of GH and PRL genes and production traits. Korean J. Anim. Sci. 38 (1996), 321-336

COSMAN, D.; LYMAN, S.D.; IDZERDA, R.L.; BECKMANN, M.P.; PARK, L.S.; GOODWIN, G.; MARCH, C.J.: DYBUS, A.:

A new cytokine receptor superfamily. Trends Biochem. Sci. 15 (1990), 265

Associations between Leu/Val polymorphism of growth hormone gene and milk production traits in Black and White cattle. Arch. Tierz., Dummerstorf 45 (2002), 421-428 
DYBUS, A.; KMIEC, M.; SOBEK, Z.; PIETRZYK, W.; WISNIEWSKI, B.:

Association between polimorphisms of growth hormone releasing hormone and pituitary transcription factor 1 genes and production traits of Limousine cattle. Arch. Tierz., Dummerstorf 46 (2003) 6, 527534

DYBUS, A.; KMIEC, M.; WISNIEWSKI, B.; WIERZBICKI, H.:

Polymorphism of the growth hormone gene in Limousine cattle. Czech J. Anim. Sci. 47 (2002), 76-79

DYBUS, A.; SWATOWSKA, I.; CZERNIAWSKA-PIATKOWSKA, E.; GRZESIAK, W.; WOJCIK, J.; RZEWUCKA, E.; ZYCH, S.:

PIT1-HinfI gene polymorphism and its association with milk production traits in polish Black and White cattle. Arch. Tierz., Dummerstorf 47 (2004) 6, 557-563

EPPARD, P.J.; BENTLE, L.A.; VIOLAND, B.N.; GANGULI, S.; HINTZ, R.L.; KUNG, L.JR.; LANZA, G.: Comparison of the galactopoietic response to pituitary-derived and recombinant-derived variants of bovine growth hormone. J. Endocrinol. 132 (1992), 47-56

GROCHOWSKA, R.; SNOCHOWSKI, M.; ZWIERZCHOWSKI, L.; REKLEWSKI, Z.; DYMNICKI, E.; OPRZADEK, J.:

Association of GH gene polymorphism and GH release following injection of TRH in Friesian cattle. Proceedings of the 48th EAAP (1997), 244

HEDIGER, R.; JOHNSON, S.E.; BARENDSE, W.; DRINKWATER, R.D.; MOORE, S.S.; HETZEL, J.:

Assignment of the growth hormone gene locus to 19q26-qter in cattle and to 11q25-qter in sheep by in situ hybridization. Genomics 8 (1990), 171-174

KAZMER, G.W.; BARNES, M.A.; AKERS, R.M.; PEARSON, R.E.:

Effect of genetic selection for milk yield and increased milking frequency on plasma growth hormone and prolactin concentration in Holstein cows. J. Anim Sci. 63 (1986) 4, 1220-7

KAZMER, G.W.; BARNES, M.A.; PEARSON R.E.:

Growth hormone and prolactin response to sire selection and increased milking frequency. J. Dairy Sci., 66 Suppl. 1. (1983), 263

LEE, B.K.; CROOKER, B.A.; HANSEN, L.B.; CHESTER-JONES, H.:

Polymorphism in the third intron of somatotropin (bST) gene and its association with selection for milk yield in Holstein cows. J. Anim. Sci. 72 Suppl.1 (1994a), 316

LOVENDAHL, P.; HOLM, L.E.; SORENSEN, P.:

Possible effect of growth hormone gene polymorphism on GH release in dairy calves. Rewiev of $48^{\text {th }}$ EAAP Meeting (1997), GPhP4.27

LUCY, M.C.; HAUSER, S.D.; EPPARD, P.J.; KRIVI, G.G.; CLARK, J.H.; BAUMAN, D.E.; COLLIER R.J.: Variants of somatotropin in cattle: gene frequencies in mayor dairy breeds and associated milk production. Domestic Animal Endocrinology, 10 (1993), 325-333

OPRZADEK, J.; DYMNICKI, E.; ZWIERZCHOWSKI, L.; LUKASZEWICZ, M:

The effect of growth hormone, $\kappa$-casein and $\beta$-lactoglobulin genotypes on carcass traits in Friesian bulls. Animal Science Papers and Reports 17 (1999), 85-92

SABOUR, M.P.; LIN, C.Y.:

Association of bGH genetic variants with milk production traits in Holstein cattle. Anim. Genet., 27 (Suppl.2.) (1996), 105

SABOUR, M.P.; LIN, C.Y.; SMITH, C.:

Association of genetic variants of bGH with milk production traits in Holstein cattle. J. Anim. Breed. Genet. 114 (1997), 435-442

SCHLEE, P.; GRAML, R.; SCHALLENBERGER, E., SCAMS, D.; ROTTMANN, O.; OLBRICH-BLUDAU,

A.; PIRCHNER, F.:

GH and IGF-1 concentrations in bulls of various GH genotypes. Theor. Appl. Genet. 88 (1994), 497500

SEAVEY, B.K.; SINGH, R.N.P., LEWIS, U.J.; GESCHWIND, I.I.:

Bovine growth hormone: evidence for two allelic forms. Biochem. Biophys. Res. Comm. 43 (1971), 189-195

SHARIFLOU, M.R.; MORAN, C.; NICHOLAS F.W.:

Association of Leu127 variant of the bovine growth hormone (bGH) gene with increased yield of milk, fat, and protein in Australian Holstein Friesians. Aust. J. Agric. Res., 51 (2000), 515-522

SHARIFLOU, M.R.; MORAN, C.; NICHOLAS, F.W.:

Candidate genes for production traits in dairy cattle. Proceedings of the 6th World Conf. Genet. Appl. Lives. Prod. (1998), 25. 043

SIROTKIN, A.V.; CHRENEK, P.; MAKAREVICH, A.V.; HUBA, J.; BULLA J.: Interrelationships between breed, growth hormone genotype, plasma IGF-level and meat performance in bulls of different ages. Arch. Tierz., Dummerstorf 43 (2000) 6, 591-596

VÁGI, J.; BARANYI, M.: 
Association between milk protein genotypes and milk production and fertility in Hungarian Holstein Friesian, Hungarian Flekvieh and Hungarofries herds. Állattenyésztés és Takarmányozás 49 (2000), 107-119

WOYCHIK, R.P.; CAMPER, S.A.; LYONS, R.H.; HOROWITZ, S.; GOODWIN, E.C.; ROTTMAN, F.M.: Cloning and nucleotid sequencing of the bGH gene. Nucleic Acid Research 10 (1982), 7197-7220

WOOD, D.C.; SALSGIVER, W.J.; KASSER, T.R.; LANGE, G.W.; ROWALD, E.; VIOLAND, B.N., JOHNSON, A.; LEIMGRUBER, R.M.; PARR, G.R.; SIEGEL, N.R.; KIMACK, N.M.; SMITH, C.E.; ZOBEL, J.F.; GANGULI, S.M.; GARBOW, J.R.; BILD, G.; KRIVI, G.G.:

Purification and characterization of pituitary bovine somatotropin. J. Biol. Chem. 264 (1989), 1474114747

ZHANG, H.M.; BROWN, D.R.; DENISE, S.K.; AX, R.L.:

Nucleotide sequence determination of a bovine somatotropin allele. Anim. Genet. 23 (1992), 578

ZHANG, H.M.; BROWN, D.R.; DENISE, S.K.; AX, R.L.:

PCR-RFLP analysis of the bovine somatotropin gene. J. Anim. Sci. 71 (1993a), 2276

ZHANG, H.M.; MADDOCK, K.C.; BROWN, D.R.; DENISE, S.K.; AX, R.L.: BGH gene frequencies in samples of U.S. AI bulls. J. Anim. Sci. 71 Suppl.1. (1993b), 93

ZWIERZCHOWSKI, L.; LUKASZEWICZ, M.; DYMNICKI, E.; OPRZADEK, J.:

Polymorphism of growth hormone $\kappa$-casein and $\beta$-lactoglobulin genes in growing Friesian cattle. Animal Science Papers and Reoprts 16 (1998), 61-68

ZWIERZCHOWSKI, L.; OPRZADEK, J.; DYMNICKI, E.; DZIERZBICKI, P.:

An association of growth hormone, -casein, -lactoglobulin, leptin and Pit-1 loci polymorphism with growth rate and carcass traits in beef cattle. Animal Science Papers and Reports 19 (2001), 65-77

Received: 2004-11-17

Accepted: 2005-08-03

Corresponding Author

Dr. KATALIN KOVÁCS

Gesztenyés str. 1.

2053-HERCEGHALOM

HUNGARY

E-mail: atk@atk.hu 